\title{
Pollution Abatement Strategy and the Dichotomy of "Green" Versus "Non-green" Products: A New Analytical Insight
}

\author{
Jules-Eric Tchapchet Tchouto ${ }^{1}$ D $\cdot$ Gérard Duthil $^{2} \cdot$ Luc Savard $^{3}$. \\ Romaine Doline Ngo Nguéda Radler ${ }^{1}$
}

Received: 25 June 2021 / Accepted: 14 January 2022

(c) The Author(s), under exclusive licence to Springer Science+Business Media, LLC, part of Springer Nature 2022, corrected publication 2022

\begin{abstract}
This paper shows how a strategy of reducing greenhouse gas emissions combined with economic cycles can lead to particular consumption behaviours. We are assuming the existence of an "economic" demand for "non-green" goods and a "social" demand for "green" goods. We are also assuming the existence of a dispersion of household characteristics organised around an average profile in each class. In times of sustained economic recession, incomes of individual agents fall. Therefore, the budgetary constraint becomes stronger, and falling incomes will have a negative impact on the demand for "green" goods. Consumers with higher incomes will reduce their demand for "green" goods, creating pressure on prices and quantities. As consumers abandon the "green" goods market, they will switch to the "nongreen" goods market, especially as prices are lower there, which will stimulate demand and create a new upward pressure on the demand for "non-green" goods.
\end{abstract}

Keywords Green and non-green products · Dual markets · Demand and supply behaviours · Economics cycles and situations · Distributional impacts · Computable General Equilibrium modelling · Tradable Emissions permits

Codes JEL C68 $\cdot \mathrm{D} 12 \cdot \mathrm{H} 23 \cdot \mathrm{Q} 11 \cdot \mathrm{Q} 52$

\section{Introduction}

Over time, the green economy, which appeared years ago, has established itself not only as a concept but also as the ideological framework for a new organisation in the structuring of consumption and production methods. Although these methods are in

Jules-Eric Tchapchet Tchouto

julerict@yahoo.fr

Extended author information available on the last page of the article 
line with the commitments of major guidelines resulting from the international conferences on the environment since Rio Summit in 1992, emphasis is placed on the transition to sustainable consumption and production in order to achieve the objectives of sustainable development (see ONU, 1992).

Achieving a change in consumption patterns (OECD, 2002) requires a transformation of the supply side of production. Therefore, it allows us to observe that the objective of minimising negative environmental impacts inherited from consumption and production systems is taken into account in a context governed by "laissezfaire." The new general framework of public policies has therefore been equipped with operational tools to confirm this transformation of supply, which can be seen as a real paradigm shift, and to move towards a path of economic, social and environmental sustainability.

The emergence of a genuine production chain for so-called "green" goods, distinguished by clearly identified and specific characteristics, as well as essential differentiation criteria derived from "green products" production techniques, is part of these major changes in the structure of supply. Sometimes referred to as a fad, the emergence of this "green" category of goods is at the margin and displayed at a higher unit price, compared to the equivalent conventional goods produced in a rather standard way.

In OECD countries in general, and in France in particular, the "green or organic" production sector is experiencing considerable growth. Similarly, direct and indirect jobs are created in this sector (see Eurostat 2020 data). As of end 2018, 61,768 operators were already active in the organic production sector at all stages of the chain, an increase of nearly $60 \%$ in less than 10 years, compared to $2010^{1}$ (Agence Bio data, 2010). According to the French Agency for the Development and Promotion of Organic Farming, nearly $90 \%$ of a representative sample of French population claim to have already consumed "organic" products, and about $75 \%$ consume them regularly, while $14 \%$ consume them daily.

Though there is significant variation between different categories of consumers in terms of frequency, it may be easy to deduce the likely causes of such variability. Considering the type of goods represented by "green" or "organic" products, we adopt in this study, as an explanatory criterion, the hypothesis of economic situations directly linked to the evolution of economic conditions that could affect household income levels to various degrees. Thus, this could allow them to show their willingness to consume or not consume "green or organic" products, or to modulate the quantity in the composition of the basket of goods selected, or even the regularity of the consumption rate. Following the same logic, we define in this study the concept of households' fringe, which consists of the proportion that falls into a given level of consumption according to economic situations.

The initial analytical framework is that of a computable general equilibrium model designed to analyse the distributional effects of reducing the quantity of tradable emission permits. As one of the direct induced effects is a decrease in aggregate

\footnotetext{
1 At the end of 2010, 20,604 farmers were active in organic farming. This is an increase of $25 \%$ compared to 2009 and $55 \%$ compared to 2008 .
} 

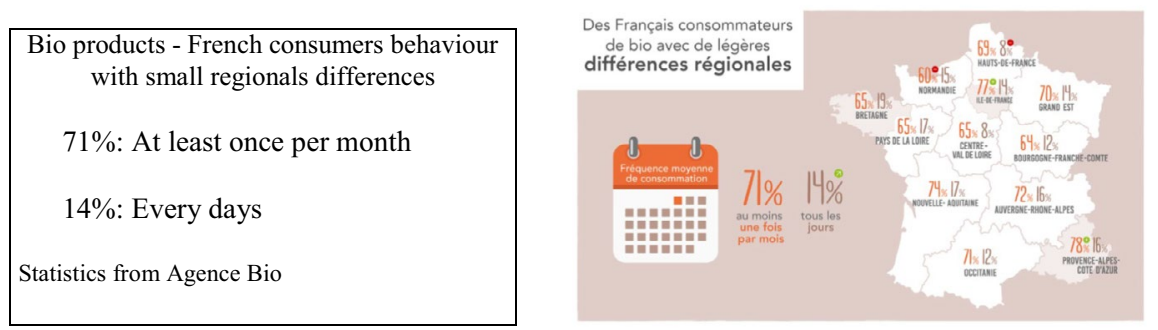

Fig. 1 Consumption frequencies of "green or bio" products within households by region Source: Agence Bio

supply which leads to a decrease in aggregate consumption, the results reveal differentiated reactions (to the implemented environmental policy) among households disaggregated by income category (capitalist and wage-earning households).

Furthermore, we make complementary hypothesis of the existence of a demand for "non-green" goods known as "economic" and a demand for "green or organic" goods known as "social"; and, by also assuming the implicit existence of a dispersion of household characteristics based on an average profile in each class, the introduction of a sustainable development strategy combined with the characterisation of cyclical economic situations may give rise to particular behavioural developments or dynamics at the level of consumption within different fringes that make up each of the heterogeneous classes of household.

With regard to the above, further reading of the article is organised as follows: "Some "Green or Bioproducts" Statistics and Literature Review" presents the current status of organic farming, a brief literature review and the motivation for this study. "Model Synthesis and Simulation Results" briefly discusses the characteristics of the model, "Preliminary Results" proposes the analytical developments deduced from the simulation results, and the last section concludes.

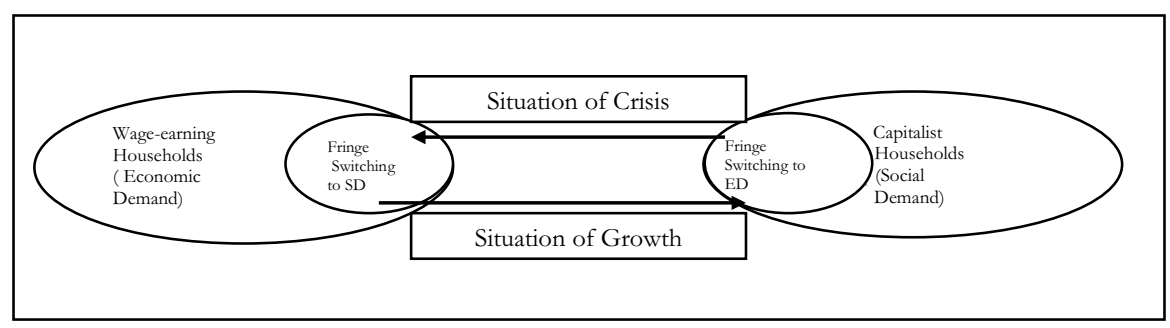

Graph 1 Economic situations and changing consumption patterns of household class fringes 


\section{Some "Green or Bioproducts" Statistics and Literature Review}

According to Agence Bio (2020), green agriculture represented 7.5\% of usable agricultural area (UAA), which represents approximately 2 million hectares. In the same year, sales of "green or bio" products in France experienced a net increase of $15.7 \%$ compared to the year 2017, increasing to 9.7 billion Euros in turnover. Figure 1 illustrates the consumption frequency of "bio or green" products by French households and across the country (See Fig. 1).

Over the same period, purchases of "green" products in the European Union of 28 represented nearly 40 billion Euros made by the 325,000 farmers who managed nearly 13.5 million useful agricultural areas. In the same year, this turnover alone represents a good part of the "green" market in the world, that is to say nearly 100 billion Euros for nearly 2.9 million farms, over a total useful agricultural surface of 70 million hectares.

Although the "green or bio" market is constantly growing in Europe and in the world, the literature on the subject and the tools we are using for this study are scant. We will first present a brief literature on the framework of analysis, namely, computable general equilibrium modelling, before exploring some works related to "green" products as opposed to "non-green" products.

General computable equilibrium models ${ }^{2}$ are well known for their use in assessing the distributional effects, including the welfare impacts, of reform policies implemented in an economy at a given time: trade liberalization (Cockburn, 2004; Boccanfuso \& Savard, 2008); poverty, inequality and development policies (Decaluwé et al., 1999, 2001, 2005; Savard, 2003; Boccanfuso et al., 2009) educational policies (Cloutier et al., 2008) and environmental policies (Piggott \& Whalley, 1992; Burniaux et al., 1992; Schubert, 1991; Schubert \& Letournel, 1991; Schubert, 1993; Beaumais \& Schubert, 1994, 1999; European Commission, 1995; Xie \& Saltzman, 2000; Bergman \& Herkerson, 2003); and distributional impacts of Covid-19 (Chitiga-Mabugu et al., 2021, ...etc.).

Models dedicated to the evaluation of environmental policy effects do not focus particularly on the dynamics of consumption, as considered in this study. Moreover, no assumption is made about any form of distinction of goods based on their intrinsic characteristics.

In the recent literature and with reference to the hypothesis of disaggregation of consumer goods into "green" and "non-green" products, this intuitive idea is similar to the work of Beaumais and Schubert (1994). Actually, they consider the hypothesis of a total consumption per capita composed of "standard" products and "green" products. Our approach differs in that we assume that the preference between the two types of goods is explicit. Contrary to these works, our approach does not aim at evaluating an indicator of environmental quality affected by unsustainable production and consumption patterns. Brécard (2008) uses the idea of a dichotomy between "polluting" or "non-green" goods distinguished from "green" products, but rather in a vertical differentiation model, with the objective of highlighting the effects of introducing an ad valorem tax. ${ }^{3}$ Shen et al. (2019) determine

\footnotetext{
2 Cf. Schubert (1993).

3 Based on product value.
} 
the optimal product line design for green and non-green products in terms of quality differentiation (Lim et al., 2018), using a two-echelon supply chain under gametheoretical framework. They demonstrate that regardless of the difference in product quality between green and non-green that reflects high and low quality, low willingness to pay for responsibility will lead consumers to a single product line strategy instead of a two-product line strategy. Moreover, improving product quality has a positive impact on environmental quality and on welfare. Murali et al. (2019) study the differentiation in product quality through the impact of environment label controls of green product development. Bahrani and Khamseh (2020) investigate the competition of green and non-green goods in a situation where dominant non-green product retailers are challenged by new suppliers who produce green products in a game theory framework. Optimality in decisions is determined for the type of alliance made by the retailer and greenness degree of the challenging green product.

\section{Model Synthesis and Simulation Results}

The analytical framework used in this study is based on the EXTER model (Decaluwé et al., 2001) which was modified in its original version. It is a multisectoral static computable general equilibrium model in an open economy, with three factors of production (Capital, Labor and Environment link with a Cobb-Douglas relation under a constant return to scale) and designed for the analysis of greenhouse gas emission reduction strategies and developed by Tchapchet Tchouto (2012). The assumption of a 3-factor production function allows through the "environment factor," to model in a numerical variant the demand of emission permits. This distinction was made from the essentially theoretical approach to this same hypothesis in the work of Beltrati (1996), Ono (2002), Jouvet et al. (2002, 2005a, 2005b), Lambrecht (2005), Jouvet \& Prieur (2006).

The model is calibrated with data from the French economy using a social accounting matrix (SAM-3F) (Table 1) includes 9 production sectors, one of which is essentially dedicated to the production of "green" goods and is excluded from the emission quota constraint. In addition, apart from the Market Services and NonMarket Services sectors, the other six are subject to the National Allocation Plan (NAP) and, therefore, to specific emission permits. They are therefore considered as the source of pollution, and their production constitutes the so-called non-green products. This 9 -sector production model $^{4}$ consists of 311 equations for 359 variables, of which 311 are endogenous and 48 exogenous.

The economic agents are made up, on the one hand, of households classified into two sub-groups: capitalist households that receive the rent from capital and the second sub-group, wage-earning households; Firms carry out production by using a production technology with constant returns to scale. On the other hand, the State collects tax revenues and makes distributions to needy households. Finally, since the

\footnotetext{
${ }^{4}$ GAMS codes and available on request from the authors, or refer to Tchapchet-Tchouto (2012).
} 
economy is open, flows with foreign countries and operations on the world market are proof of the existence of the rest of the world.

Simulation within the framework of the environmental policy evaluated here will consist of a 5\% reduction in the quantity of emission permits initially available. This exogenous downward variation thus constitutes the principle of environmental constraint which guides the strategy of de-pollution efforts.

In the context of this study, our analytical approach will focus more on deepening the dynamics of consumption in relation to economic situations. This allows us to analyse the behaviour of the "social" demand for "green" products and the "economic" demand. We will focus more on the part of the simulation results that concerns the primary objective of this study whilst publishing the complete simulation results in the Appendix (Table 2). However, detailed equations of the model are available in Decaluwé et al. (2001).

\section{Preliminary Results}

The immediate consequence of the depollution strategy implemented is an increase in producer prices which is reflected in to consumer prices. According to economic theory, it is therefore easy to anticipate at this stage the impact on consumer demand of goods whose prices increase in favour of those categories of households whose income is negatively affected. In fact, the results of the model show a fall in wages and therefore in the income of wage-earning households and conversely an increase in the income of capitalist households, resulting from the rise in the return on capital costs.

One of the first conclusions we came up with is that depollution measure, introduced through the effect of variation in the quantity of permits, generates inequity between different classes of households and thus inter-generational inequity.

In addition, simulation results show a negative relationship in the short term between producer prices per unit of output, domestic prices or consumer prices and the quantity of final products available by sector of activity. Thus, for a given general price level, there is a shift in the product supply curve from right to left, indicating a decline in overall supply.

\section{Analytical Developments of the Results, Teachings and Contributions}

\section{Economic Situations, Household Categories, and Consumption Behaviour}

Within each of the two distinct classes of households characterised by the nature of their income, there are heterogeneous household profiles in this selected classification. This assumption makes it possible to implicitly consider a dispersion 
Graph 2 Supply of "green" and "non-green" goods

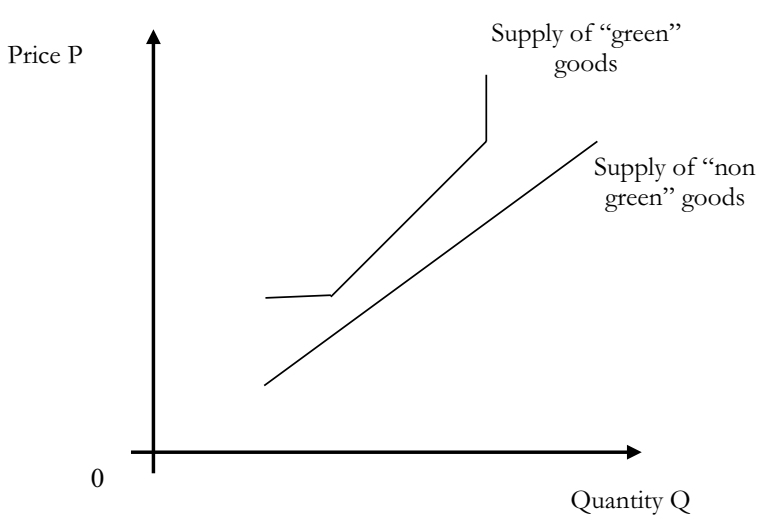

of household characteristics organised around an average profile in each class. It reflects the idea that, depending on the economic situation (crisis or growth), the most fragile fringe of households (the case of the capitalist category of households) will change their mode of consumption by abandoning the "green" good (Graph 1). Similarly, the most affluent fringe of households in the dispersion of wage-earning household profiles will change their consumption pattern, abandoning the "non-green" good. Graph 3 further explains the situation described in this hypothesis.

\section{Supply and Demand Structure of "Green" Goods}

Hypothesis 1: Let us assume that the market is twofold segmented (Culbertson, 1957).

There is thus a dual market of a "green or organic" aggregate good (Sub-Market A) and a "non-green" aggregate good (Sub-Market B). The offer is divided into a "green or organic" offer and a "non-green" offer. Therefore, these offers respond respectively to two demands: one from high-income consumers (buyers of "green" goods) and the other from lower-income consumers (buyers of "non-green" goods).

\section{Supply-Side Assumptions}

Hypothesis 2: Based on social cost theory associated with externalities as pointed out by Coase $(1960,1988)$ and Kapp (1971), we can define the goods supply function framework. While the supply of "non-green" goods depends increasingly on the price of this type of goods, the supply of "green" agricultural goods is twice as "angled" (see Graph 2). This is due to higher production costs of "green" goods, whereby the supply of these goods is constrained by a minimum price on the market. If the price is below a minimum level, the supply of "green" goods is zero, as they are not competitive on the market. It becomes quite elastic when the price is equal to a minimum level up to a given quantity. 
Graph 3 Demand of "green" and "non-green" goods

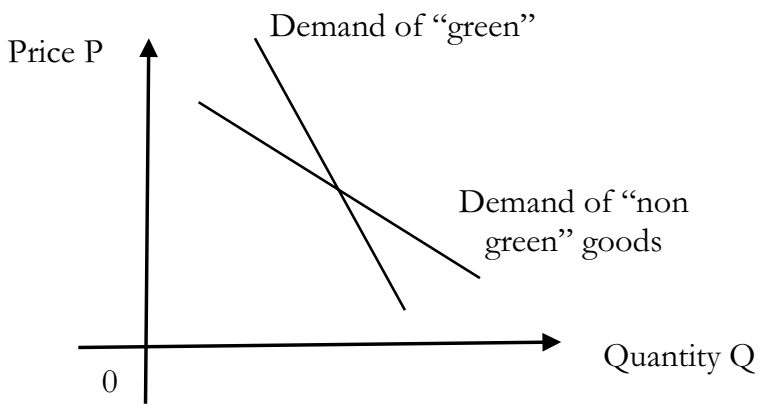

Secondly, supply depends on price. However, the social value of "green" goods is higher than economic value of "non-green" goods. Thus, producers can sell "green" goods at a higher price, but in smaller quantities than "non-green" goods, since they offer their goods to the high-income consumer market segment.

Finally, supply becomes a vertical. Production quantities of green goods are rationed by increasing production difficulties or failure to increase production due to a lack of suitable land for cultivation ${ }^{5}$ or necessary inputs or by the farmer's desire not to exceed "normal yields" for such production. Supply curve then becomes perfectly inelastic to price.

\section{Demand-Side Assumptions}

Regarding demand, based on Krugman and Wells (2009) supply and demand model hypothesis, there are two elements to be considered. Firstly, it is argued that consumption of "green" goods has benefits for the economic agent who sees his or her health status being higher than that of an agent who consumes "non-green" goods. By increasing its human capital, it improves its productivity at work and its remuneration. Thus, the social value of the green good is higher than its economic value, so that consumers are willing to pay more for "green" products than for "non-green" products. However, consumers must have a certain income to access such consumption (see Graph 3).

Thus, two market segments are opposed by the separation of the two social groups A first group, with high incomes, will express a demand for the consumption of the "green or organic" good known as "social", relatively rigid, and therefore is not very sensitive to price variations. Higher prices make little difference to the demand of such consumers. This demand depends inversely on the price and has a very steep slope. A second group, with lower incomes, will express a demand known as "economic" and relatively elastic which is the consumption of the "nongreen" good. Price changes will strongly affect such consumer demand. A small decrease in prices will imply a large increase in the quantities consumed. Demand depends inversely on price and is not very steep.

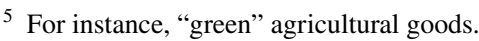




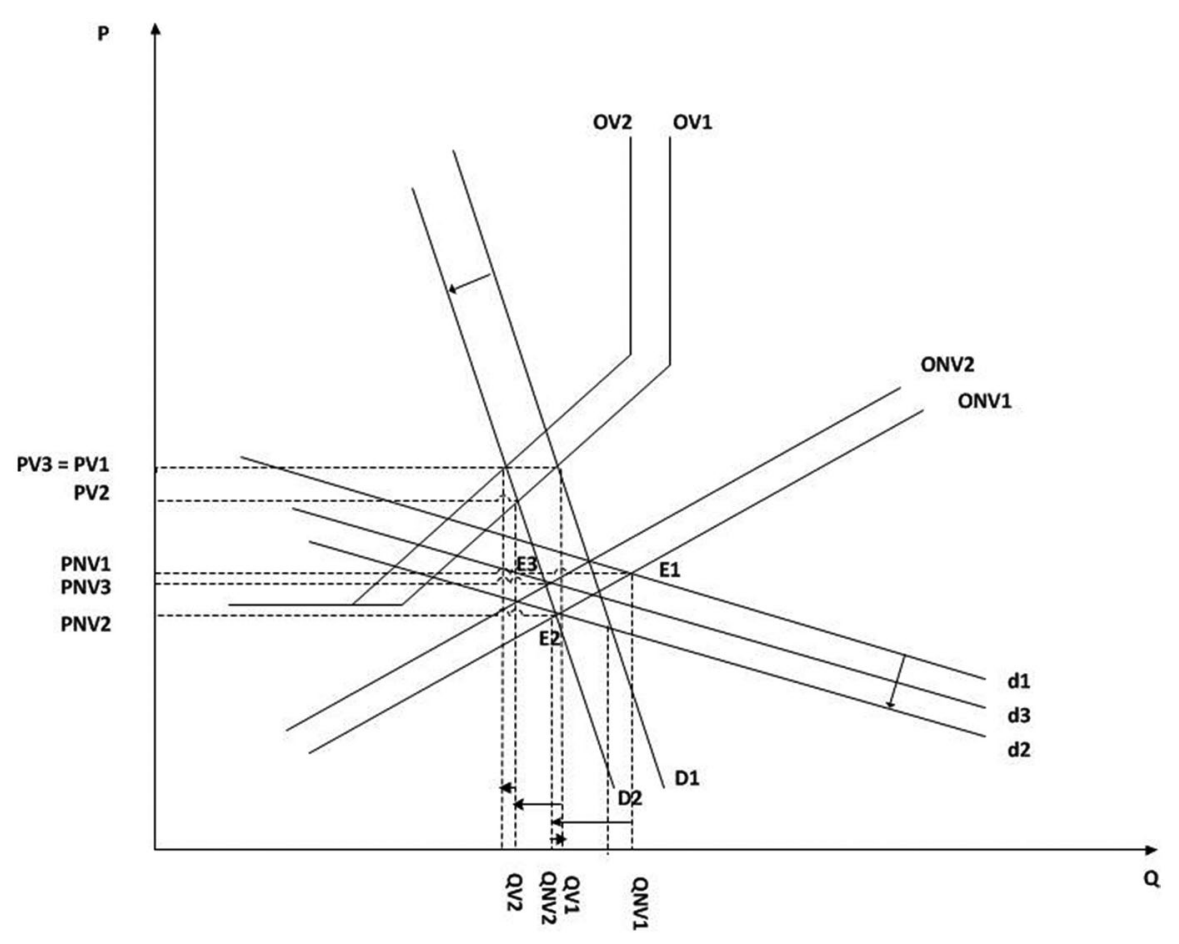

Graph 4 Market equilibrium of "green” and "non-green” goods

Finally, as the two types of producers do not have a concerted policy on price and quantity, or even compete with each other, the two market segments are not watertight. Thus, some consumers will move from one market to another depending on uncertainties, particularly economic ones (variations in income received or available).

\section{Market Equilibrium}

Market equilibrium is determined by comparing supply and demand on the two submarkets (see Graph 4), which makes it possible to establish prices and exchange quantities. In the green goods market, the Eg equilibrium is given by $(\mathrm{Qg}, \mathrm{Pg})$; in the non-green goods market, the Eng equilibrium is given by (Qng, Png). It is noteworthy that the price of green goods is higher than the price of non-green goods and that the quantities traded on the green segment are lower than the quantities traded on the non-green goods market, which is consistent with the assumptions stated above.

We can therefore question the stability of these balances in phases of economic growth or recession. 


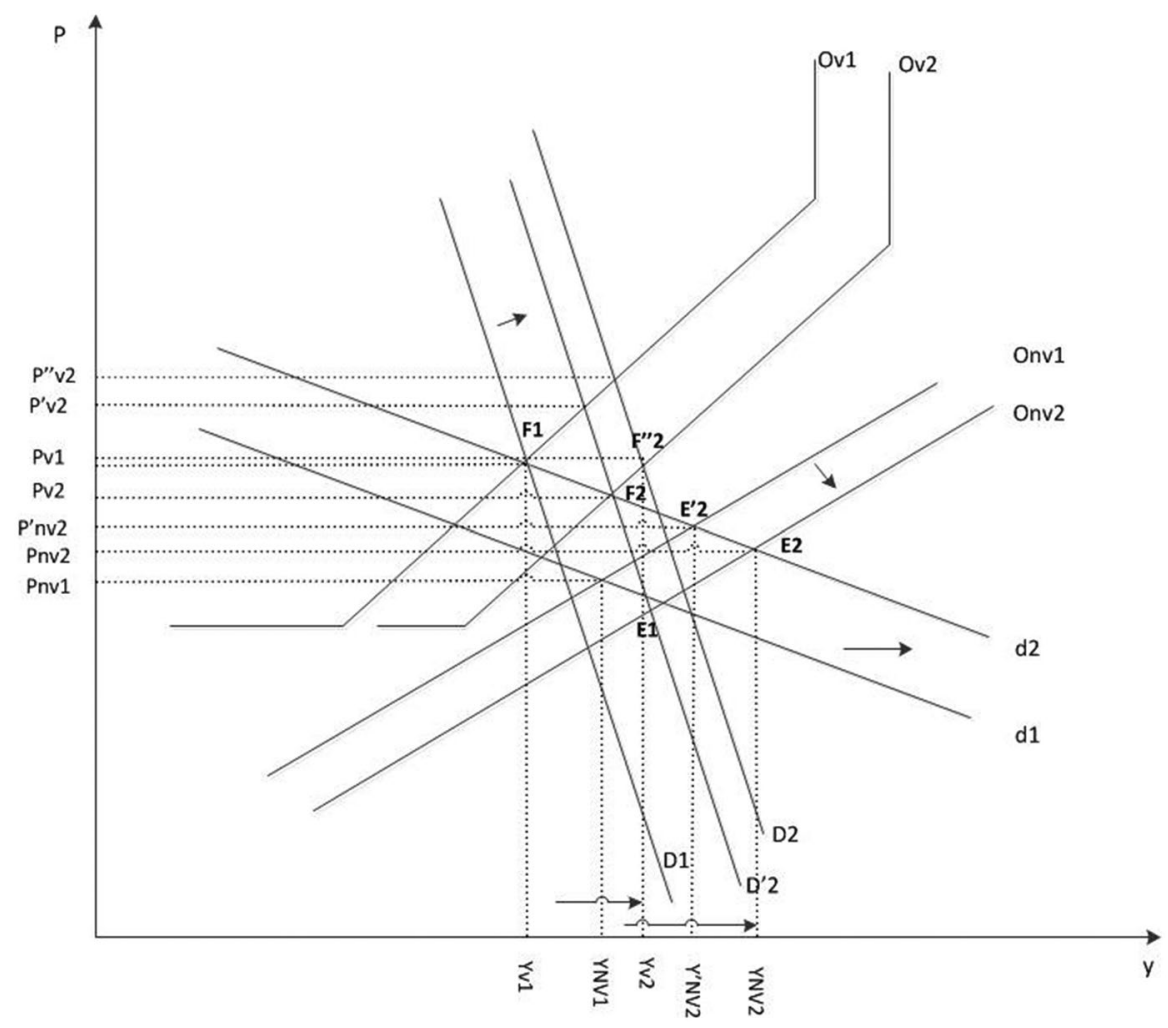

Graph 5 Impacts on the equilibrium of sub-markets

\section{Consumption in Growth Phase}

In periods of sustained economic growth, incomes of individual agents increase. As the budget constraint is less strong, consumers with lower incomes increase their demand for "non-green" goods (D1 to D2) Prices will rise in this market, stimulating the supply of "non-green" goods (ONV1 to ONV2). However, some of these consumers will also access consumption of "green" goods, albeit at higher prices, which will dampen demand and create downward pressure on demand for "nongreen" goods (D2 to D3) (see Graph 5).

The supply of goods then adjusts downwards. As a result of these various effects, prices on the market for "non-green" goods will change little, and the quantities traded will strongly increase.

Similarly, rising incomes will have a positive impact on the demand for "green" or "organic" goods. Consumers with higher incomes will increase their demand for "green" goods, creating pressure on prices and quantities. Suppliers increase the quantities on the market in response to increased demand from both types of consumers. Prices are highly responsive to changes in supply and demand, and eventually increase slightly. Due to the rigidity of supply, quantities evolve less strongly than in the other segment. 


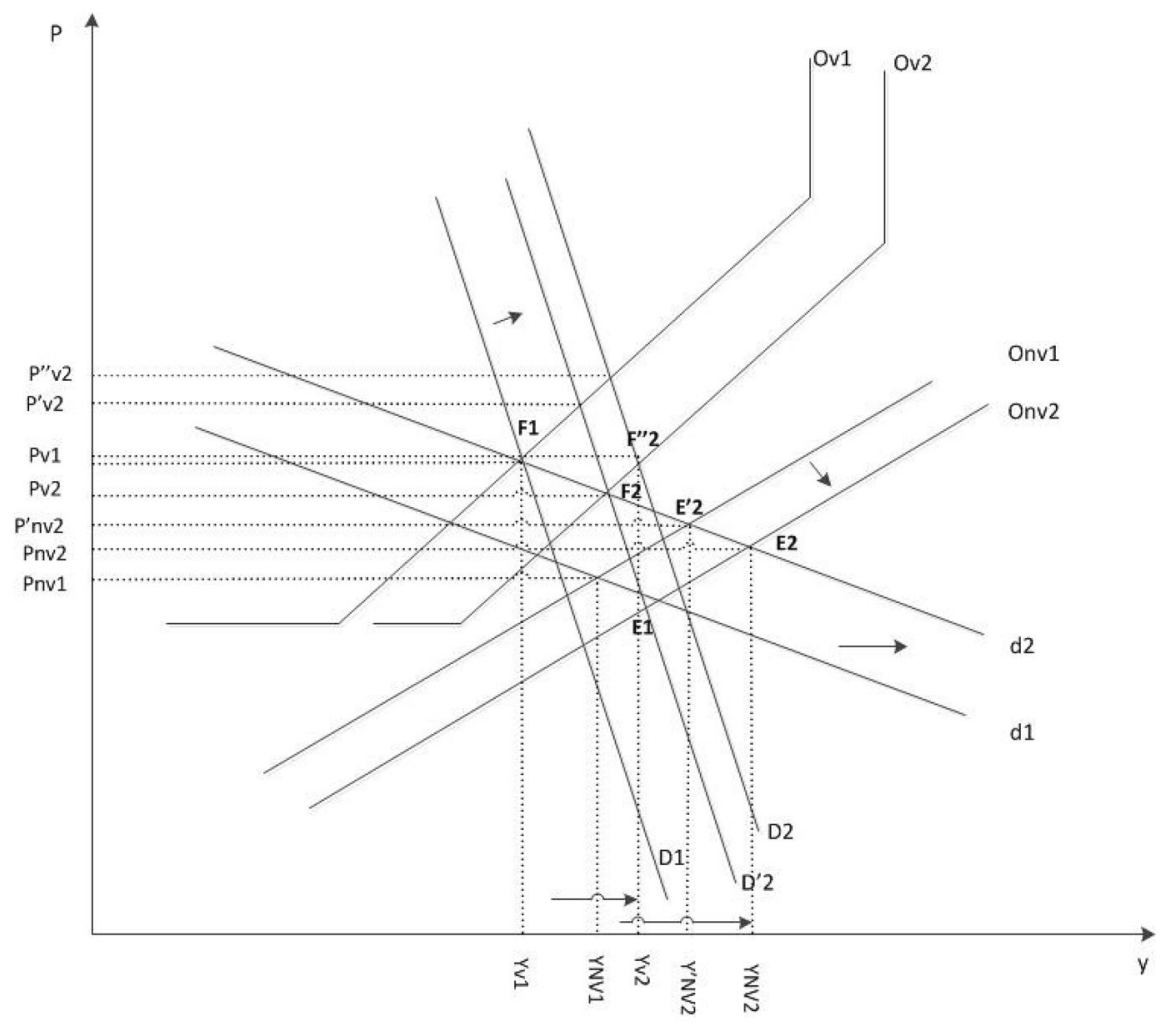

Graph 6 Impacts on the equilibrium of sub-markets

The impact on quantities appears to be lower in the market for "green" or "organic" goods than in the market for "green" goods, despite a clear increase in demand for these goods. Prices for "green" goods remain higher. However, the price gap between the markets remains almost identical. In other words, the growth in demand for "green or organic" goods is linked to improved economic growth, but the "green" sector does not benefit more than the "non-green" sectors. Yet we could not have believed that the economic upturn and income growth were conducive to the development of a green economy, albeit with higher production costs and prices.

\section{Consumption in Recession}

In times of sustained economic recession, incomes of individual agents fall. The budgetary constraint becomes stronger and consumers with lower incomes clearly reduce their demand for "non-green" goods (D1 to D2, see Graph 6). Prices are falling in this market, curbing the supply of non-green goods (ONV1 to ONV2). Quantities traded on this market are strongly decreasing and the prices are also falling. 
Likewise, falling incomes will have a negative impact on the demand for "green" goods. Consumers with higher incomes will reduce their demand for "green" goods, creating pressure on prices and quantities. Suppliers then limit the quantities on the market in response to fluctuating consumer demand. Prices are falling, especially as consumers with lower incomes move out of the "green" goods market and into the "non-green" goods market. As supply and demand for green goods change, the quantities traded fall, but the price remains stable, due to the greater rigidity of supply and demand than in the other segment.

As consumers abandon the green goods market, they will switch to the non-green goods market, especially as prices are lower there, which will stimulate demand and create a new upward pressure on the demand for "non-green" goods (D2 to D3). As a result of these various effects, prices in the non-green goods market will hardly change from the initial level, but the quantities traded have strongly decreased.

Once again, it appears that the impact on prices is low, regardless of the market (green goods/non-green goods). The prices of both types of goods do not alter significantly and the price gap between the markets is almost identical. In other words, a phase of economic recession does not imply a drop in the price of "green" goods, even if the quantities traded on the market decrease. The non-green sector is experiencing lower demand and prices are slightly falling.

The recession phase is particularly unfavourable to the development of a green economy, as production costs and prices are higher and the drag on consumer incomes increases the trade-off between "non-green" and "green" goods to the detriment of the latter. It is wise to assume that the shift in consumption towards "green or organic" goods can only take place during a period of income growth, after awareness.

Assuming that economic situation resulting from the simulation is similar to a contraction of economic activity, the shifts in the demand and supply curves for goods are confirmed by the simulation results (see Table 2-Appendix) Production in the "non-green" and "green or organic" sectors is decreasing, as is domestic demand for the various types of goods. The price movement in the graph describing the domestic market trend does not take into account the existence of taxes. In fact, the interpretation of the evolution of prices should take into account the increase in taxes on production, which is also reflected in prices on the domestic market.

\section{Conclusion}

Introduction of environmental protection policies within the framework of sustainable development strategies has led to a dichotomous trend in the development of endproducts in the field of consumer goods production. Although differentiated according to their nature and method of production and resulting from the anchoring of sustainable development in the customs, "green" or "organic" products and "non-green" products which coexist allow us to reveal, through our analysis, variable consumption behaviours.

Considering the simulation results of a computable general equilibrium model as a starting point, the objective of this study is to provide new insights from analytical 
developments, based on assumptions that take into account the behaviour of households, but also the often varying economic situations. Within a household class, the composition can be heterogeneous according to the income level curve (wage or pension). This approach makes it possible to characterise household fringes and, above all, end fringes within each class, initially geared either towards an "economic" demand or a "social" demand with regard to a given standard income level. In fact, "green or organic" products are inherently more accessible to higher-income households and "non-green" products more to lower-income households.

Under the hypothesis of the existence of an "economic" demand for "non-green" goods and a "social" demand for "green" goods, and also assuming the implicit existence of a dispersion of household characteristics organised around an average profile in each class, we have shown in this article how the introduction of a sustainable development strategy combined with the characterisation of economic situations can give rise to, or be at, the origin of consumption behaviours that are specific to each class and each end fringe.

Under the effect of random cyclical variations characterised here by economic situations depending on whether we are in a period of crisis or growth, end fringes forming within each group will switch for wage earning households (economic demand) to a social demand and thus consume more "green or organic" products (growth situation). Conversely, in a crisis situation, the lower fringe of capitalist households (social demand) will switch to economic demand in order to compensate for the effect of the transitory loss of income.

Under the dual market and supply/demand assumptions, we determine the market equilibrium conditions for "green" and "non-green" goods under the stated assumptions. We then examine in greater detail the conditions for the stability of these equilibria obtained during phases of economic growth or recession, by clarifying demand and supply behaviour, as well as prices.

We conclude that the product differentiation that emerges from the implementation of an institutional decision, based on a desire to preserve the environment and thus intergenerational equity, generates real problems of intergenerational inequity, and more precisely within each of the heterogeneous classes of households. ${ }^{6}$ Thus, such a result could guide the action of public policies implemented within the framework of environmental preservation policies, in order to consider compensatory transfers for poor households. Furthermore, economic foresight could also be directed towards the production sectors with production support policies such as tax exemptions, with the aim of lowering production costs so that more "green or organic" products are available and accessible to the greatest number.

Some policies implications can be derived from this study and results. First, the existence of a green sector can lead to different industrial policies prac-

\footnotetext{
${ }^{6}$ Using an alternative modelling approach, it would be possible to consider heterogeneity according to the precepts of life-cycle theory (working and retired); it would then be possible to determine which class of households would be more affected by the environmental policy strategy introduced. This would rather be done within the framework of a dynamic overlapping generations model (see TchapchetTchouto (2012), and the static approach adopted in this study is not appropriate.
} 
tices. Policy makers might be invited to address measures in favour of the "green" production sector that uses production methods with a low level of impact on the environment. Secondly, regarding the price contest between green and non-green producer as the demands of the products are dependent on sales price, products impacts on the Environment, corporate social responsibility, policies makers can offer higher subsidy to green goods producers. Moreover, they can introduce different tax schemes on production factors such as labour and capital to make the sector more attractive to investments, and lower tax policies schemes to the green producers and as point out by SankarSana (2020), unlike lower subsidy and higher tax to the non-green goods producers. Therefore, consumption of green products will be disconnected from income and economic fluctuations. Thirdly, the intervention of public authorities through an effective institutional involvement would galvanize the green market. This could promote green jobs as well as green market, and strengthen the implementation of a green economy. 


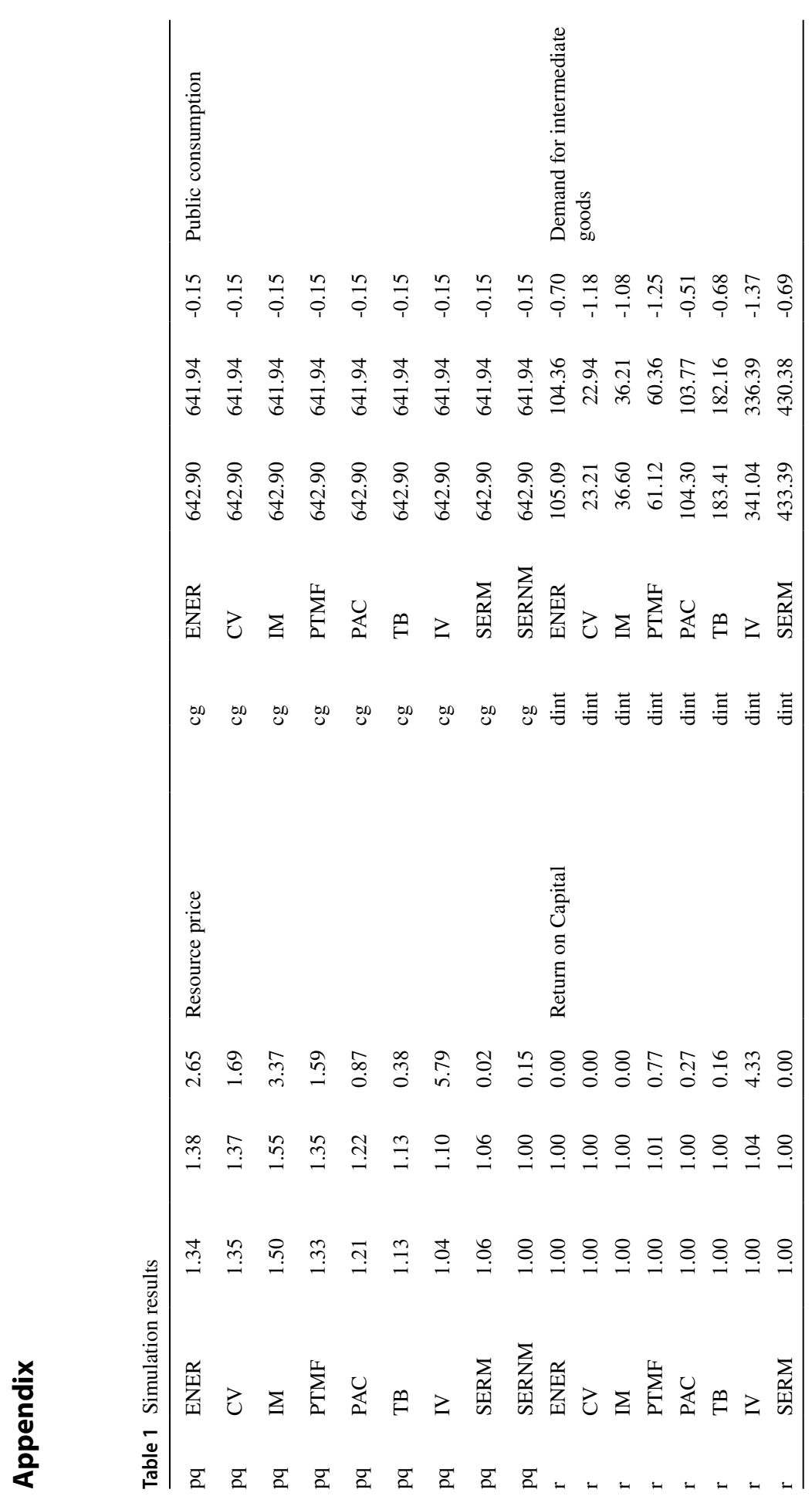




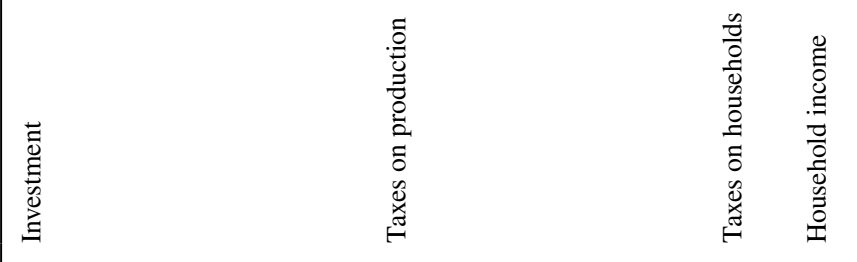

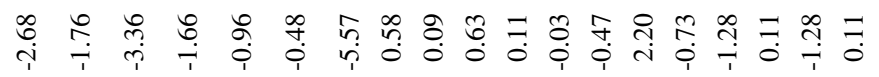

そ) ก

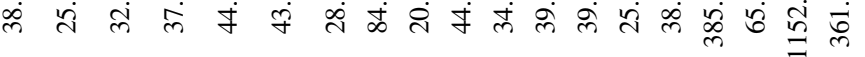

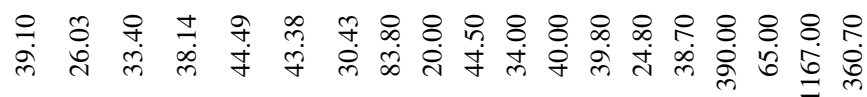

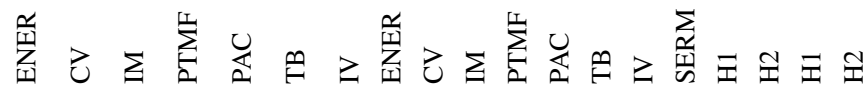

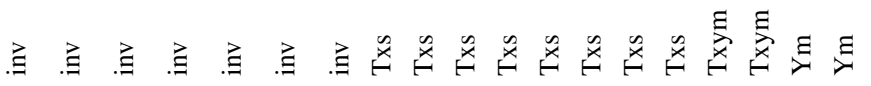

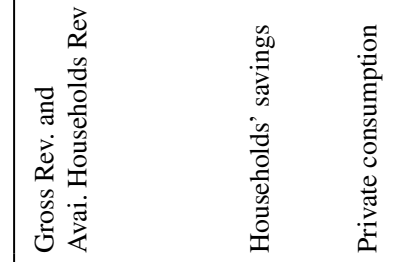

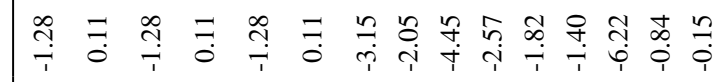

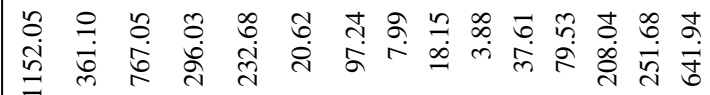

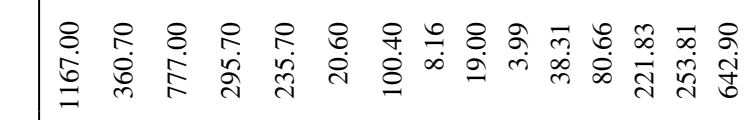


Table 2 Social accounting matrix (MCF-3F)—with France Data: 3 factors and 9 production sectors

\begin{tabular}{|c|c|c|c|c|c|c|c|c|c|c|c|c|c|c|c|c|c|c|}
\hline & & \multicolumn{3}{|l|}{ Factors } & \multicolumn{5}{|l|}{ Agents } & \multicolumn{9}{|c|}{ Sectors } \\
\hline & & L & $\mathrm{K}$ & E & $\mathrm{HI}$ & $\mathrm{H} 2$ & En'ses & Gow & ROW & Ener & $\mathrm{CV}$ & IM & PTMF & PPC & $\mathrm{TB}$ & Ind-V & SM & $\mathrm{SNM}$ \\
\hline & & 1 & 2 & 3 & 4 & 5 & 6 & 7 & 8 & 9 & 10 & 11 & 12 & 13 & 14 & 15 & 16 & 17 \\
\hline L. & 1 & & & & & & & & & 51.95 & 15.00 & 21.50 & 80.40 & 51.00 & 120.15 & 38.00 & 300.90 & 187.40 \\
\hline K & 2 & & & & & & & & & 17.1 & 9.00 & 18.20 & 20.40 & 24.60 & 59.90 & 261.20 & 160.00 & \\
\hline E & 3 & & & & & & & & & 17.3 & 10.00 & 21.60 & 25.90 & 28.40 & 9.00 & & & \\
\hline $\mathrm{H1}$ & 4 & 865.40 & & & & & & 301.60 & & & & & & & & & & \\
\hline $\mathrm{H} 2$ & 5 & & 19490 & & & & 16580 & & & & & & & & & & & \\
\hline En'ses & 6 & & 344.30 & 112.20 & & & & & & & & & & & & & & \\
\hline Gov & 7 & & & & 390.00 & 65.00 & 15520 & & & & & & & & & & & \\
\hline ROW & 8 & & 31.20 & & & & 75.00 & & & & & & & & & & & \\
\hline Ener & 9 & & & & & & & & & & & & & & & & & \\
\hline $\mathrm{CV}$ & 10 & & & & & & & & & & & & & & & & & \\
\hline IM & 11 & & & & & & & & & & & & & & & & & \\
\hline PTMF & 12 & & & & & & & & & & & & & & & & & \\
\hline PPC & 13 & & & & & & & & & & & & & & & & & \\
\hline TB & 14 & & & & & & & & & & & & & & & & & \\
\hline Ind-V & 15 & & & & & & & & & & & & & & & & & \\
\hline SM & 16 & & & & & & & & & & & & & & & & & \\
\hline SNM & 17 & & & & & & & & & & & & & & & & & \\
\hline Encer & 18 & & & & 66.90 & 67.90 & & & & 3.80 & 6.40 & 5.30 & 6.00 & 4.05 & 2.15 & & 33.10 & 80.30 \\
\hline $\mathrm{cr}$ & 19 & & & & 4.00 & 7.00 & & & & 0.09 & 2.80 & 3.50 & 2.80 & 0.00 & 4.20 & & 6.00 & 12.00 \\
\hline IM & 20 & & & & 27.50 & 1.00 & & & & 1.25 & 3.60 & 2.45 & 3.60 & 10.00 & 1.80 & & 23.00 & 9.20 \\
\hline PTMF & 21 & & & & 4.30 & 1.00 & & & & 11.30 & & 6.00 & 14.85 & 0.00 & 2.00 & & 29.10 & 18.00 \\
\hline $\mathrm{PPC}$ & 22 & & & & 36.00 & 10.50 & & & & & & & & 5.50 & 6.00 & & 62.00 & 53.10 \\
\hline тв & 23 & & & & 74.50 & 16.60 & & & & 2.00 & 17.00 & 4.90 & 1.50 & 8.00 & 30.25 & & 28.80 & 114.70 \\
\hline Ind-V & 24 & & & & 149.10 & 82.00 & & & & 41.25 & 10.10 & 45.40 & 29.60 & 1245 & 41.00 & 126.70 & 42.80 & 6.00 \\
\hline $\mathrm{sM}$ & 25 & & & & 179.00 & 89.10 & & & & 91.95 & 1.40 & 3.35 & 1.20 & 59.10 & 45.00 & 85.00 & 8.60 & 16220 \\
\hline SNM & 26 & & & & & & & 2.90 & & & & & & & & & & \\
\hline Ener & 27 & & & & & & & & 25.30 & & & & & & & & & \\
\hline $\mathrm{CV}$ & 28 & & & & & & & & 28.90 & & & & & & & & & \\
\hline IM & 29 & & & & & & & & 47.20 & & & & & & & & & \\
\hline PTMF & 30 & & & & & & & & 105.00 & & & & & & & & & \\
\hline PPC & 31 & & & & & & & & 20.00 & & & & & & & & & \\
\hline TB & 32 & & & & & & & & 23.00 & & & & & & & & & \\
\hline Ind-V & 33 & & & & & & & & 61.60 & & & & & & & & & \\
\hline $\mathrm{sM}$ & 34 & & & & & & & & 123.10 & & & & & & & & & \\
\hline Saving & 35 & & & & 235.70 & 20.60 & 60.50 & -3.70 & 10.00 & & & & & & & & & \\
\hline & & 865.40 & 570.40 & 112.20 & 1167.00 & $\begin{array}{l}\text { \#\# } \\
\text { \# }\end{array}$ & 456.50 & 940.80 & 444.10 & 237.90 & 75.30 & 13220 & 186.25 & 203.10 & 321.45 & 510.90 & 693.40 & 64290 \\
\hline & & 865.40 & 570.40 & 112.20 & 1167.00 & $\begin{array}{l}\# \# \# \\
\#\end{array}$ & 456.50 & 940.80 & 444.10 & 237.90 & 75.30 & 13220 & 186.25 & 203.10 & 321.45 & 510.90 & 693.40 & 642.90 \\
\hline & & 0.00 & 0.000 & 0.00 & 0.00 & 0.00 & 0.00 & 0.00 & 0.00 & 0.00 & 0.00 & 0.60 & 0.00 & 0.00 & 0.00 & 0.00 & 0.00 & 0.00 \\
\hline
\end{tabular}




\begin{tabular}{|c|c|c|c|c|c|c|c|c|}
\hline \multicolumn{9}{|c|}{ Composites Products } \\
\hline Enerer & cv & IM & PTAF & PPC & тв & $\operatorname{Ind} \mathrm{I} V$ & $\mathrm{sM}$ & SNM \\
\hline 18 & 19 & 20 & 21 & 22 & 23 & 24 & 25 & 26 \\
\hline & & & & & & & & \\
\hline & & & & & & & & \\
\hline & & & & & & & & \\
\hline & & & & & & & & \\
\hline & & & & & & & & \\
\hline & & & & & & & & \\
\hline 83.80 & 20.00 & 4.50 & 34.00 & 40.000 & 30.80 & 2480 & 38.70 & \\
\hline 3200 & 11.00 & 4.00 & 22.00 & 4.00 & 9,00 & 139.00 & 116.90 & \\
\hline \multicolumn{9}{|l|}{21260} \\
\hline & 46.40 & & & & & & & \\
\hline & & 85.000 & & & & & & \\
\hline & & & 81.25 & & & & & \\
\hline & & & & 183.10 & & & & \\
\hline & & & & & 208.45 & & & \\
\hline & & & & & & 45430 & & \\
\hline & & & & & & & 570.30 & \\
\hline & & & & & & & & 6290 \\
\hline & & & & & & & & \\
\hline & & & & & & & & \\
\hline & & & & & & & & \\
\hline & & & & & & & & \\
\hline & & & & & & & & \\
\hline & & & & & & & & \\
\hline & & & & & & & & \\
\hline & & & & & & & & \\
\hline & & & & & & & & \\
\hline & & & & & & & & \\
\hline & & & & & & & & \\
\hline & & & & & & & & \\
\hline & & & & & & & & \\
\hline & & & & & & & & \\
\hline & & & & & & & & \\
\hline & & & & & & & & \\
\hline & & & & & & & & \\
\hline & & & & & & & & \\
\hline 328.40 & 77.40 & 13350 & 13725 & 227.10 & 3425 & 618.10 & 725.90 & 642.90 \\
\hline 328.40 & 77.40 & 13350 & 137.25 & 227.10 & 3425 & 618.10 & 725.90 & 64290 \\
\hline 0.00 & 0.000 & 0.00 & 0.00 & 0.00 & 0.000 & 0.00 & 0.00 & 0.00 \\
\hline
\end{tabular}




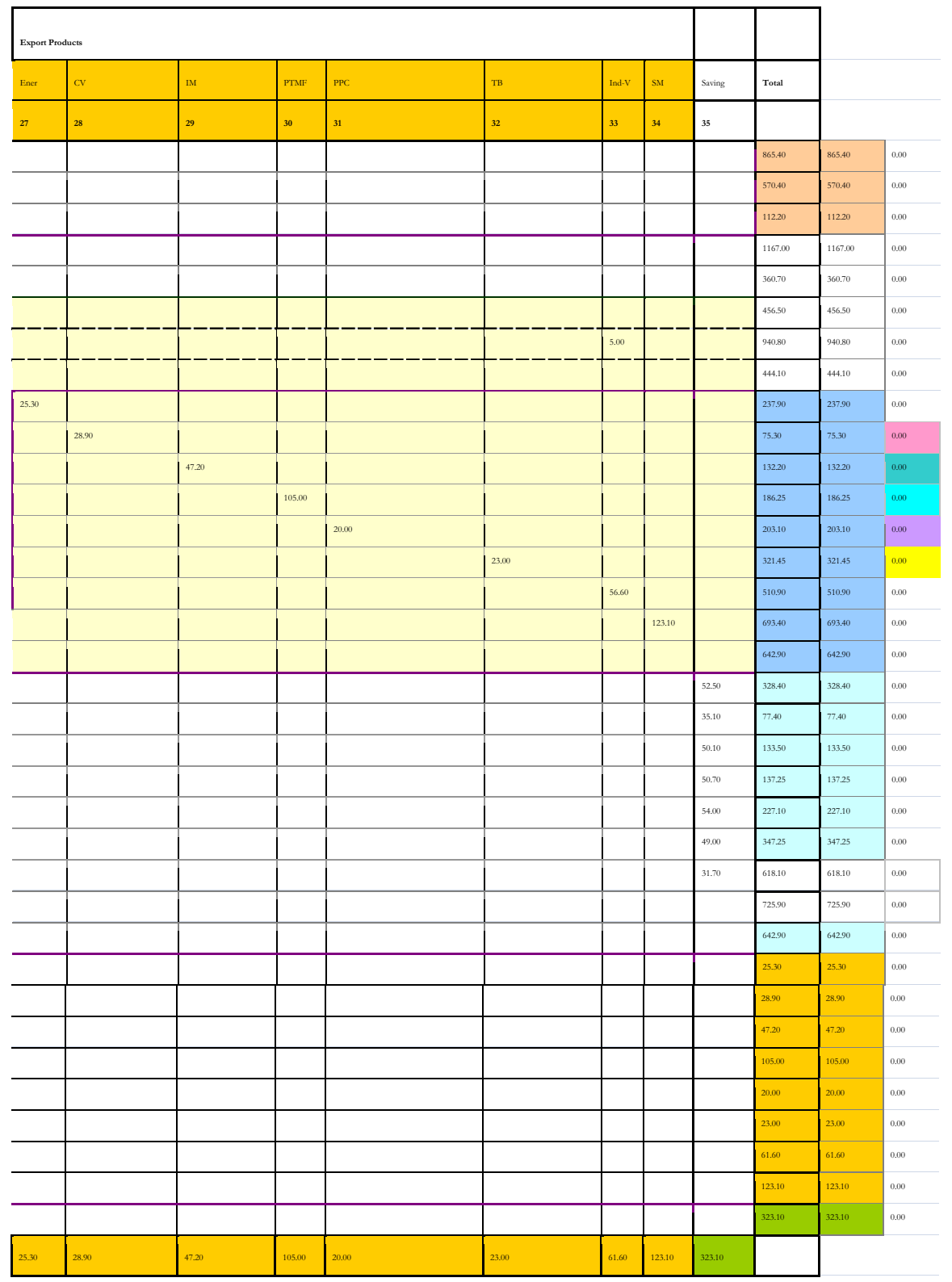


Acknowledgements We would like to sincerely thank the two anonymous reviewers and the Editor-inChief, Dr Elias G. Carayannis, for their helpful comments and suggestions on the previous draft of this article. The usual disclaimer apply and views are the sole responsability of the authors.

Funding The corresponding author (Jules-Eric Tchapchet Tchouto) declares that for this research project, he has received PhD Excellence fellowship funding/financial support from The Ministry of Higher Education, Research and Innovation in France; The Dean's Award for the Faculty of Administration (University of Sherbrooke, Québec); and The Europe-Maghreb Postdoctoral mobility Excellence Fellowship from the European Union.

Availability of Data and Material Data of the social accounting matrix are available upon request to the authors.

Code Availability We used GAMS software which need a license. GAMS Code is available upon request to reproduce the results in the table.

\section{Declarations}

Conflict of Interest All authors declare no competing interests.

\section{References}

Agence Bio. (2010). 'La bio en France, de la production à la consommation', Les chiffres clés en 2010.

Agence Bio. (2020). 'L'agriculture biologique', Les chiffres clés en 2018.

Bahrani, P., \& Khamseh, A. A. (2020). Competitive Environment Between Green and Non-green Products Considering Disruption and Alliance Strategy. Global Journal of Flexible Systems Management, 21, 135-161.

Beaumais, O., \& Schubert, K. (1994). Equilibre Général et environnement : De nouveaux comportements pour le consommateur et le producteur. Revue Économique, 45(3), 905-916.

Beaumais, O., \& Schubert, K. (1999). La modélisation en équilibre général calculable [Un regard sur les interactions économie/environnement]. Economie rurale, Programme National Persée, 251(1), 25-32.

Beltrati, A. (1996). 'Emissions permits in a dynamic model with overlapping generations', Nota Di Lavoro 4395 .

Bergman, L., \& Herkerson, M., (2003). CGE modeling of evironmental and resource management. Working Paper Stockholm School of Economics.

Boccanfuso, D., Estache, A., \& Savard, L. (2009). Impact Analysis of Electricity reforms in Senegal: A Macro-micro analysis. Journal of Development Studies., 45(3), 351-375.

Boccanfuso, D., \& Savard, L. (2008). Groundnut sector liberalization in Senegal: A multi-household CGE analysis. Oxford Development Studies, 36(2), 159-186.

Brecard, D. (2008). Une note sur la taxation advalorem des produits polluants sur un marché vert. Revue Économique, Presses De Sciences Po, 59, 487-496.

Burniaux, J-M., Martin, J-P., Nicoletti, G., \& Oliveira-Martins, J. (1992). GREEN, a multi-sector, multiregions general equilibrium model for quantifying the costs of curbing $\mathrm{CO} 2$ emissons: a technical manual. OCDE Working Paper $\mathrm{n}^{\circ} 116$.

Chitiga-Mabugu, M., Henseler, M., Mabugu, R., \& Maisonnave, H. (2021). Economic and Distributional Impact of COVID-19: Evidence from Macro-Micro Modelling of the South African Economy. South African Journal of Economics, 89(1), 82-94. https://doi.org/10.1111/saje.12275

Cloutier, M. H., Cockburn, J., Decaluwe, B. (2008). 'Education and poverty in Vietnam: a computable general equilibrium analysis', Cahier de Recherche 0804, CIRPEE.

Cockburn, J. (2004). 'Trade liberalisation and poverty in Nepal: a computable general equilibrium micro Ssimulation analysis', Development and Comp Systems, 0409012, EconWPA.

Commission Europeenne. (1995). 'GEM-E3 computable general equilibrium model for studying economy-energy-environment interaction', OPEC, Luxembourg.

Coase, R. (1960). The problem of social cost", in: Journal of Law and Economics, Vol. 3.

Coase, R. (1988). Note on the problem of social costs in: The Firm, the Market, and the Law. Chicago: University of Chicago Press. 
Culbertson, J. (1957). The term structure of interest rates. Quarterly Journal of Economics, 71, 485-517. https://doi.org/10.2307/1885708

Decaluwé, B., Martens, A., Savard, L. (2001). 'La politique économique du développement et les modèles d'équilibre général calculables', Les Presses de l'Université de Montréal.

Decaluwé, B., Patry, A., Savard, L., \& Thorbecke, E. (1999). 'Poverty analysis within a general equilibrium framework', Paper 9909, Laval - Recherche en Politique Economique.

Decaluwé, B., Savard, L., \& Thorbecke, E. (2005). General equilibrium approach for poverty analysis with an application to Cameroon. African Development Review, 17(2), 213-243.

Jouvet, P. A., Michel, P., Vidal, J. P. (2002). 'Effets des permis de pollution sur l'accumulation du capital dans le cadre des modèles à générations imbriquées', Economie et Prévision n ${ }^{\circ} 156$, pp. 63-72, La Documentation française.

Jouvet, P. A., Michel, P., Rotillon, G. (2005a). Equilibrium with pollution permits. Research in Economics, 59.

Jouvet, P. A., Michel, P., \& Rotillon, G. (2005b). Optimal growth with pollution: How to use pollution permits? Journal of Economic Dynamics \& Control, 29, 1597-1609.

Jouvet, P. A., Prieur, F. (2006). 'Permis de pollution et contraintes politiques dans un modèle à générations imbriquées', Document de travail - Economix (publié dans Annales d'Economie et Statistiques, 2009).

KAPP, W. (1971). The Social Costs of Private Enterprise. Schocken Books.

Krugman, P., Wells, R. (2009). Macroeconomics, worth publisher, second edition.

Lambrecht, S. (2005). 'Maintaining environmental quality for overlapping generations', version révisée du Climneg Working Paper ${ }^{\circ} 59$.

Lim, W., Mak, V., Tang, C., Raghabendra, K. C. (2018). Adopting cost transparency as a marketing strategy: Analytical and experimental exploration, working paper at National University of Singapore.

Murali, K., Lim, M. K., \& Petruzzi, N. C. (2019). The Effects of Ecolabels and Environmental Regulation on Green Product Development. Manufacturing and Service Operations Management, 21(3), 519-535. https://doi.org/10.1287/msom.2017.0703

OCDE. (2002). Towards Sustainable Household Consumption? Trends and Policies in OECD Countries. La Documentation française.

Ono, T. (2002). The effects of emission permets on growth and the environment. Environmental \& Resource Economics, Spinger, European Association of Environmental and Resource Economists, 21(1), $75-87$.

ONU. (1992). 'Action 21, Chapitre 4: Modification des modes de consommation', Programme des Nations Unies pour l'Environnement.

Piggot, J., Whalley, J. (1992). 'Economic impacts of carbon reduction schemes: Some general equilibrium estimates from a simple global model’, CESifo Working Paper Series n ${ }^{\circ} 17$.

Sankar Sana, S. (2020). Price competition between green and non-green products under corporate social responsible firm, Journal of retailing and Consumer Services. 55. https://doi.org/10.1016/j. jretconser.2020.102118

Savard, L. (2003). 'Poverty and income distribution in a CGE-household micro-simulation model: Topdown/bottom up approach', Cahier de recherche 0343, CIRPEE.

Schubert, K. (1991). Note sur l'équivalence entre impôts dans un cadre d'équilibre général en économie fermée. Economie et Prévision, Programme National Persée, 98(2), 137-142.

Schubert, K. (1993). 'Les modèles d'équilibre général calculables : une revue de la littérature' (General equilibrium models : A litterature review). Revue d'économie Politique, 103(6), 775-825.

Schubert, K., \& Letournel, P.-Y. (1991). Un modèle d'équilibre général appliqué à l'étude de la fiscalité française. Economie et Prévision, Programme National Persée, 98(2), 83-99.

Shen, B., Cao, Y., Xu, X. (2020). Product line design and quality differentiation for green and non-green products in supply chain. International Journal of Production Research, 58(1). https://doi.org/10. 1080/00207543.2019.1656843

Tchapchet Tchouto, J. E. (2012). Contraintes d'Emissions de GES et modélisation économique : Perspectives alternatives, enseignement et contributions au regard des approches appliquées et théorique de l'équilibre général; (Thèse de doctorat, Université de Rouen, www.theses.fr).

Xie, J., \& Saltzman, S. (2000). 'Environmental policy analysis: An environmental computable general equilibrium approach for developing countries. Journal of Policy Modelling, 22(4), 453-489.

Publisher's Note Springer Nature remains neutral with regard to jurisdictional claims in published maps and institutional affiliations. 
Springer Nature or its licensor holds exclusive rights to this article under a publishing agreement with the author(s) or other rightsholder(s); author self-archiving of the accepted manuscript version of this article is solely governed by the terms of such publishing agreement and applicable law.

\section{Authors and Affiliations}

\section{Jules-Eric Tchapchet Tchouto ${ }^{1}$ (D) Gérard Duthil ${ }^{2}$ - Luc Savard ${ }^{3}$. Romaine Doline Ngo Nguéda Radler ${ }^{1}$}

Gérard Duthil

gerard.duthil@univ-rouen.fr

Luc Savard

savard.luc@um6p.ma

Romaine Doline Ngo Nguéda Radler

nguedadoline@hotmail.de

1 Department of Public Economics, Faculty of Economics and Management, University of Dschang, Dschang, Cameroon

2 LERN, UFR Droit, Sciences Economiques et de Gestion, Université de Rouen, 3, Avenue Pasteur, 76186 Rouen Cedex, France

3 Present Address: AIRESS, Faculty of Governance, Economics and Social Sciences, Mohammed VI Polytechnic University UM6P, Benguerir, Technopolis Rabat-Shore Rocade Rabat-Salé, Rabbat 11103, Morocco 